\title{
Протоко лы
}

\section{ЗАСБДАНИЙ АКУУЕРССКО-РИНЕКОЛОГИЧЕСКАГО ОВЩЕСТВА ВЪ КІЕВБ}

\section{№ 82 .}

\section{3 марта 1896 года.}

\section{Предспдательствовалг проф. Л. А. Малиновскій.}

Присутствовали: Д. А. Абуладзе, Д. А. Воробьевъ, М. Ө. Вознесенскій, Ю. А. Гижицкій, Н. С. Гржибовскій, В. Ш. Жемуужниковь, Н. М. Звинятскій, К. К. Кеглерь, Г. Г. Левицкій, Н. П. Марьянчикъ, П. Т. Нейштубе, С. В. Петриковскій, Г. Ф. Писемскій, Н. Н. Подрбзанъ, А. А. Редлихь, С. А. Тулубъ, Н. В. Унтиловъ, А. П. Чхонтовъ и 55 гостей.

1) Прочитань и утверждень протоколь предыдущаго засъданія.

2) Библіотекаремь сообщено о полученіи на имя Общества сльгдующихъ книгъ и изданій:

Журналг Общества Русскихъ врачей въ память Н. И. Пирогова № 3, 1895 г.-Паргаминь. Насльвдственность и гигіена брака.Журналь „Акушерка“. № 3, 1896 г.

3) Д-рь C. Д. Анпольскій (гость) прочель главу (переводь) изь сочиненія Сорана Эфиесскаго «O женскихз болпзняхз . Соранъ происходить изь г. Эфеса въ Малой Азіи. Получивь

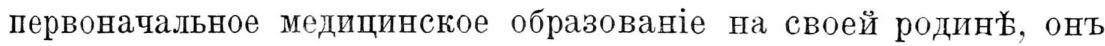
работаль для дальнййшаго усоверпенствованія въ Александріи. Побывавъ затбиь въ другихъ городахь, бывпихъ въ то время дентрами образованія, Сорань поселился въ Римъ̌, гдъ и занялся медицинской практикой. Время его дйжельности здйсь совпадаеть сь царствованіемъ Императоровь Траяна и Адріава 
(конецъ I и начало II вйка по Р. Х.). Въ Римъ Соранъ пріобрғль величайшую славу, какъ ученаго медика, такъ и врача практика. Онъ оставиль сочиненія по терапевтикь̌⿱ хирургіи, общей патологіи, бармакологіи, исторіи медицины и др. и быль лучшимъ для своего времени знатокомъ анатоміи, занимаясь изученіемъ ея на человъческихъ трупахъ. Его познанія въ анатоміи женскихъ половыхъ органовъ далеко оставляютъ за собою познанія его предшественниковь и даже превосходять неккоторыхъ посльздующихъ авторовъ въ томъ числь্ и Галена. Въ прочитанной главб («Какова природа матки и женскихь половыхъ органовъ»), объяснивъ значеніе названій матки («мэтра, гистэра, дельфусь»), С. подробно останавливается (§ 7) на топограбическомь положеніи матки, описывая ея отношенія къ мочевому пузырюу дынвочекъ, женщинь рожавшихь и нерожавпихь и во время беременности. Въ 8 описываются связки матки, ихъ измъ̆ненія: сморщиванія подъ вліяніемъ воспаленія и растяженія. Въ маткь (§ 10) С. различаеть зъвь (orificium), шейку (collum) и затылокь (cervix), и совокупность этихъ частей-рукоятку (kaula, современное cervix); далье онъ описываеть плечи (umeri), бока (latera), дно (fundus современное corpus (?) uteri). Часть лежащая внутри матки подъ дномъ-основаніе (basis), полость (cavum), брюшко (venter) и каналь (sinus). У взрослыхъ женщинъ зъвъ матки отстоить оть наружныхь частей пальщевъ на 5-6 и раскрывается во время родовъ, при половомъ возбужденіи, посль вачатія и во время менструаціи. Матка (§ 11) состоитъ изъ нервовъ, венъ, артерій и мяса. Нервы берутъ начало отъ оболочекъ спинного мозга, артеріи (двъ) и вены (двъ̌) отъ прилежащихъ по позвоночному столбу полой вены и толстой артеріи. Яичники получають по одной венъ и одной артеріи. Придатки матки расположены по одному съ каждой стороны и покрыты собственной оболочкой. "Съмянные проходы» идуть отъ обоихъ яичниковъ къ маткъ. Яичники могуть входить въ составъ паховыхъ грыжъ。 Матка (§ 13) состоить изъ двухь оболочекъ: наружная болъе богата нервами, глаже, тверже и бълье и внутренняя-мясистье, мягче, красн务е и изобилуеть кровеносными сосудами. Матка (§ 15) не безусловно необходима для жизни, она не только выпадаеть, но можеть быть даже вырбзываема. У матки есть 
природная связь еъ трудными железами. Съ измъненіями ея въ періпдеи зрблости, беременности, менструаціи, въ пожиломь возрасть́ и при смерти зародыша наступають соотвитственныя измьненія и въ железахь.

Чтеніе было поясняемо рисунками и примбччаніями переводчика.

Проф. Малиновскій выразиль удивленіе глубокой наблюдательности старыхъ авторовъ, а въ частности Сорана и его св'дыніямъ вь области топографической и описательной анатоміи женскихь половыхь органовъ. Интересный докладъ п-ра Янпольскало еще разь подтверждаеть ту мысль, нерьдко забываемую современными авторами, что при изученіи медицинскихъ вопросовъ всегда сль́дуеть начинать съ изученія старыхь авторовъ, у которнхъ нер'вдко можно найти весьма важныя и существенныя данныя.

4) Д-рг 10. А. Гиюиикій сообщиль случай уреміи посль podoвz.

Пятаго Декабря 1895 г. докладчикь быль приглашень изъ клиники къ больной родильнищ', два дня тому назадь разришившейся преждевременно живымъ плодомъ.

Изъ разспросовь оказалось, что за мйсяць до родовъ наб̆людались отеки конечностей, лица и сильныя головныя боли; беременность была первая. Посльь родовъ головныя боли не уменьшились и больная въ тоть же день впала въ сонливое состояніе и потеряла зръніе. На другой день состояніе ея здоровья еще болье ухудпилось и заставило прибъгнуть кь врачебной помощи. Докладчикь нашель больную въ полубез. сознательномь состояніи, лицо и конечности отечны, $\mathrm{t}^{0}-37,8$. Со стороны матки выражены явленія воспаленія слизистой ея

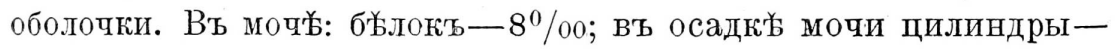
вернисгые, гіалиновые, почечный эпителій, кровяные шарики и мочекислыя соли. По изсльдованію спеціалистовъ со стороны зрьнія: amaurosis уремическаго центральнаго происхожденія; со стороны нервной системы: легкое ступорозное состояніе, упадокъ вниманія, ослабленіе памяти и амнестическая абқазія. Лъченіе: слабительныя, спорынья, промываніе влагалища 2\% растворомъ карболовой кислоты, молочная діэта и ледъ на животь. Сознаніе и зрьніе появились на 6 день, встала съ постели на 17-й. Черезь 5 недгель ухудшеніе, ради чего больная была отправлена въ Александровскую больницу ва излеченіе. 
Спустя мйсящт, она выписалась ивь больнищь сь небольшимь количествомь $\left(1 / 4^{0} / 00\right)$ бьлка и цилиндровь (гіалиновыхъ) въ мочь. Полагая, что въ данномь случағ имејлась тяжелая борма воспаленія почекь (nephritis), а не «почка беременныхъ», докладчикь обращаеть вниманіе на отсутствіе судорогъ, обстоятельство, имьююшее отношеніе кь теоріи эклампсіи. Для появленія экламптическихь судорогь, видимо, недостаточно одного отравленія организма продуктами обмтна веществь; а необходимо присутствіе еще какого-то фактора, который собственно и способствуеть появленію экламптическихь припадковь.

Вь преніяхь приняли участіе д-ра Редлихг, Писемскій, Вознесенскій, Шовогег-Детеикій (гость) и проб. Малиновскій.

Редлихг сказаль, что при страданіяхь почек'ь изь опасенія интоксикапіи сльпуеть изб́бгать промываній влагалища, а в особенности матки сильыми дезинфецирующими веществами, какь нашр., карболовая кислота. Точно также сльгдуеть быть осторожнымь и при назначеніи препаратовь спорыньи въ виду имьююихся часто въ этихь случаяхь ивмьненій нервно мыпечнаго аппарата сердца.

Писемскій. Теченіе бользни говорить скорье за то, что въ данномь случас⿱宀㠯 была именно „почка беременныхь", а не воспаленіе почекь (nephritis). Вь исторіи бользни неть никакихь указаній на то, что было страданіе почекь еще по беременности и съ другой стороны появленіе разстройствь дҺялтельности почекь только кь концу беременности, и быстрое улучшеніе больвни говори'ь в'ь пользу почки беременныхь. При-

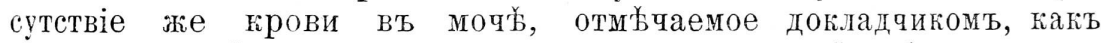
признакьь небрита, встрьчается и при почкь беременныхь

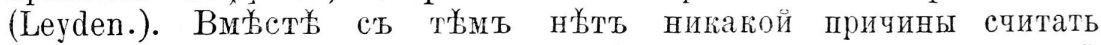
сльиоту за первый признак'ь уреміи, появившейся только посль⿱⺊口灬 родовъ: гораздо вйроятнъе шоявленіе уреміи сльдуеть отнести къ конпу беременности, когда появились головныл боли.

Вознесенскій, въ виду отсутствія измьненій въ сердцби, считаеть, что в'ь данномь случаж скор бе была почка беременныхь.

Швогерь-Детеикій замттиль что если бы было сдйлано колиqественное изсльгыованіе мочи на мочевину, то по уменьшонному количеству посльдней можно было бы судить о характер' изы неній въ почкахъ.

Проф. Малиновскій высказался также противь нефрита.

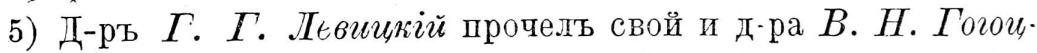
кало докладь подъ заглавіемъ "Оваріотомія иерезо прямую кигику во времл родовгг.

Еврейка 3., 24 л., правильно менструируеть съ 13 л., беременна была въ 3 разъ. Первыя дв各 беременности окончи- 
лись выкидышемь на 2 мъсядъ. Вь январъ 1895 г., на клинической ғмоулаторіи, распознана дермоидная киста праваго яичника величиною вь кулакъ, расположенная въ заднемъ дугласовомь пространствь. Посльдніе регулы 12 мая 1895 г. Ha IV мбосмд беременности поступила вь клинику для оваріотоміи во время беременности, но была выписана безъ операціи всльдствіе настойчиваго желанія больной доносить плодь до срока и вь расчеть на то, что небольшая опухоль по мйрб роста матки можеть выйти изь полости малаго таза. Второго февраля 1895 г. больная поступила въ клинику въ родахь. Тазъ: D. Sp.-24,5; D. Cr.-28,0; D. Tr.-34,0; Conj. ext.20,0. Положеніе плода продольное; опухоль совершенно неподвижна и помешается вь заднемь дугласовомь пространствъ; внутри опухоли справа мыса прощупывается небольшое костное образованіе подтвердившее діагнозь дермоида. Родовая дъятель. ность слаба. Продолжительность перваго періода родовъ 170 часовь. Кь концу этого періода головка ошустилась большимь сегментомь вь полость таза. Воды отошли на 3-й день, при зъьъ открытомъ на $2^{1 / 2}$ поперечныхъ пальпа. Къ этому времени развился colpitis sub partu; $t^{0}-38,0 ;$ P.-120; седьмого февраля 1895 г., т. е. на 5 день родовъ, в'ь 7 часовъ вечера, при вполнь раскрытомъ зъ̌ьь, на головку, стоящую большимь сегментомь вь полости таза, наложены щицпы. Опухоль при

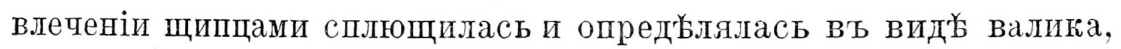
окаймляющаго головку сзади. Многократными тракцілми головка низведена кь выходу таза и стала показываться въ половой щели; въ это то время было замбчено выпячиваніе опухоли черезь раскрытое заднепроходное отверстіе; всльғъ за этимь сть্ьнка кишки надъ выпятивпимся сегментомь опухоли разорвалась.

Въ виду этого влеченіе щипцами прекращено. Черезь разрывъ кишки стьюка кисты проколота троакаромъ; содержимое дермоида выдавливалось сь трудомъ; въ виду этого отверстіе прокола расширено и тогда только опухоль была опорожнена. Посль опорожненія опухоли плодъ быль извлечень безь затрудненій, но уже мертвымъ. Въ посльгдовомь періодь-сильное атоническое кровотеченіе, которое едва удалось остановить и

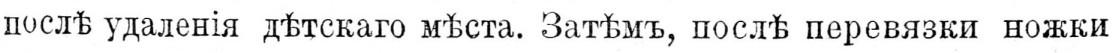


кисты, опухоль была удалена, и разрывъ кишки зашитє 14 узловатыми ппами. Киста состояла изъ двухъ отдызовъ и содержала салоподобную жидкость и костное образованіе. Посль' операціи больная умерла спустя 33 часа при явленіяхъ малокровія и воспаленія брюпины. Температура вскоръ поднялась до $38,5^{0}$ Щ., а затьмь упала до $35,8^{0}$ Ц. В бссь плода 4350 грм., длина 52,0; окружность головки 38,0 . На вскрытіи обнаружено: острый фибринозно-гнойный перитонить вь тазу, и рбъкое малокровіе. По мнъ̌нію авторовъ доклада смерть произошла отъ анеміи при ограниченномъ септическомь перитонитъ. Приведя соотвьтственную казуистику изь литературы (3 случая), докладчики сдблали заключеніе, что оваріотомію черезь прямую кишку не сльљдуетъ считать оперативнымъ методомъ, имбющимь право гражданства, а смотрбть на нее нужно какь на операцію е necessitate.

Въ преніяхъ приняли участіе д-ра Редлихг, Шуварскіи, Писемскій, Абуладзе, Анполскій, Вознесенскій, Тулубг и проф. Малиновскій.

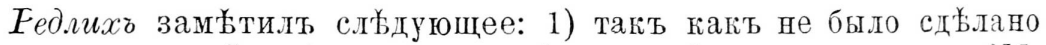
внутреннее измтреніе таза и не быль измърень плоць по $A h l$ feld'y то едвали въ данномь случағ возможно было высказывать мнъніе, что тазь обширный и ставить такимъ образоиъ благопріятный прогнозь для родовъ, т. е. что г'оловка можеть пройти мимо опухоли, а потому; 2) сльдовало бы при началь родовь попытаться вправить опухоль вверхъ изъ полости таза подь хлороформнымъ наркозомъ; и это вполнге могло имбть мисто, так' какъ при вскрытіи оказалось, что опухоль была безь срощеній и имьла длинную ножку. Вправленіе опухоли было бы во всякомъ случағ менъе рискованнымъ вмыншательствомъ въ смысль возможности нанесенія траумы, благодаря присутствію вь опухоли острыхь костныхь образованій, чъмъ наложеніе щипцовъ; 3) простой узловатый шовь, одноэтажный едвали можно считать умьсстнымъ для накладыванія на кишку; 4) причиной смерти ближе всего слььууеть считать септическое зараженіе, при чемь зараженіе могло произойти или со стороны влагалища, въ которомь до операціи быль уже опредвлень colpitis, сь повышеніеиъ темшературы, или же инфецирующія микробы могли проникнуть изъ кипки, которая не была подготовлена передъ операціей. 5) Положеніе опухоли цермоица въ заднемъ своды говорить противъ признака Küstner'a, который считаеть его патлгно-монистическимъ. Дермоидь здысь опредъля.лся въ заднемъ сводь еще въ то время, когда больная была не беременна.

Левиикій отвъ́тиль, что не было сдьлано попытокь вшравить опухоль потому, что посль'ьняя казалась совершенно непсдвижной. 
Шуварскій, Писемскій и проф. Малиновскій предложили нъооторые вопросы съ п宛ю выяснить механизмь разрыва кишки кпухолью.

Левиикій сказаль, что при наложеніи щипцовъ головка съ оцухолью находилась въ полости малаго таза. При влеченіи головки опухоль выпятила переднюю стьнку прямой кишки настолько сильно, что подь напоромь ея стьнка разорвалась.

Шуварскій. Въ то время когда посльдоваль разрывъ стьнки кишки головка показывалась уже въ половой пели. Какимь образомь разрывъ кишки, какь оказалось, шроизошель на 10 сант. выше оть заднепроходнаго отверстія? Не способствовала ли разрыву косточка, бывшая въ полости кисты?

Абуладзе. Въ разрыв'б кишки первымъ показался именно тоть отдъвль опухоли, в' которомъ находилась косточка. Что же касается внутреннихь размбров' таза, о которыхь говориль д-рь Редлихг, то разићры діагональной коньюгаты предполагались не менъе нормальныхъ, так' какь при измъреніи ел мысъ не достигался.

По мнъ̆нію д-ра Яинольскаго разрыву могли способетво-

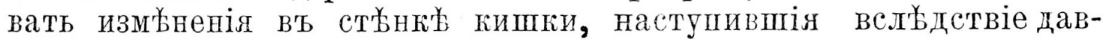
ленія во время продолжительныхъ родовъ.

Вознесенскій сказаль, что сльддовало бы опорожнить кисту разръзомь черезъ влагалище.

Левиикий замътиль, что едвали бы это удалось при такомь густомъ содержимомь опухоци.

6) Д-ръ В. Лозинскій показаль жениину сг добавочнымг. (3-мг) соскомо. Василиса 3., 35 л.; происходить изь семьи вполнг здоровой. Уродовъ, кретиновъ и психопатовъ въ семействљ̆ и между родными не было. Беременна 8 раљъ. Посльддніе роды въ акушерской клиникъ. В'ь строеніи туловища и конечностей особенностей не замбъqется. Въ строеніи лица и головы можно отмбтить нбасколько признаковъ вырожденія: ушныя сережки прирощены, лобъ узокъ, твердое нёбо стоить высоко; прогнотизмъ ржзљо выраженъ. Грудныя железы развиты хорошо, равной величины, отвислы, цольки прощупываются ясно. На правой одинъ хорошо развитой сосокъ, на л安вой-два, при чемъ одинъ, правильно развитой, расположенъ на обычномъ м'ьст'ь, другой находится на 1 сант. кверху оть нижняго края железы и на 2 сант. кнутри отъ сосковой линіи. Онъ гораздо меньшихъ размъровъ (въ горошину) и вообще имбетет видъ недоразвитого. Форма добавочнаго соска циливдро-коническая, пигментація неръзкая. Монгомеровы тьйца выражены не ясно. Разстояніе между нормальнымъ и добавочнымъ соскомъ-6 сант. 
Молоко выдавливается изъ добавочнаго соска хорошо, хотя

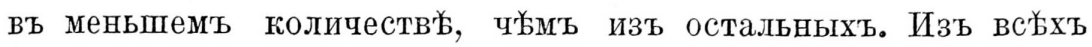
трехъ сосковъ отдъленіе молока наступило одновременно.

7) Д-рь A. I. Орловскій за позднимъ временемь ограничился только демонстраціей, отложивъ сообщеніе свое до слйдующаго засъданія. Демонстрировались два микроскопическіе препарата: 1) триперный эной, въ которомъ были ясно видны гонококки въ клйткахь и 2) иистал культура гонококковъ. Цзъ макроскопическихь препаратовъ-2 пластинчатыя культуры трипернаго гноя и нъсколько пробирокъ съ чистыми культурами гонококковъ. Питательной средой служила смъсь 2 част. М. П. А. $2^{0} / 0+1$ часть содержимаго кисты яичника; при чемъ шосльдняя бралась или профильтрованная черезъ свъqу Pasteur-Chamberlend'а, или не фильтрованная, полученная стерильною при операціи, что контролировалась въ термостать. Кром⿰ того, въ одной пробирке рость гонококковъ получился непюсредственно только на одной кистовой жидкости, свернутой при $\mathrm{t}^{0} 72^{0}$ Ц.

\section{Административное засьданіе.}

Предсь⿻дательствоваль прибывшій въ засьиданіе прод. Рейнб. Прочитаны curricula vitae предложенныхъ въ дыйситительные члевы Общества д-ровъ Даикова и Кузнещова.

Даиковг, Василій Осиповичг, родился въ 1857 году, обучался въ Кіевской І гимназіи, гд它 и окончиль курсъ въ 1875 году. По окончаніи гимназіи, поступиль на медицинскій факультеть Университета св. Владиміра и окончиль курсъ въ 1886 году со степенью лекаря съ отличіемъ. Тстчасъ по окончаніи университета (казенный стипендіать) быль командированъ Министромъ Внутреннихъ Дъзль въ Могилевскій уъздъ Подольской губ. врачемъ санитарнаго отряда для борьбы съ эпидеміей диобтерита. Въ 1891 году Медицинскимъ Факультетомъ Университета св. Владиміра назначенъ быль помощникомъ прозектора по кафедрь нормальной анатоміи но, хотя быль утвержденъ Попечителемъ Округа, не заняль этой должности въ виду несогласія Министра Внутреннихь Дъль на переходъ его, какъ казеннаго стипендіата, въ Министерство Народнаго Про- 
свъъенія. Вмъсто этого Медицинскимъ Департаментомъ быль назначенъ на должность сельскаго врача въ г. Оршу Могилевской губ. Въ томъ же 1891 году въ октябрб мйсяц' назначенъ быль убззднымъ врачемъ въ гор. Сънно Могил. губ. Въ 1892 году перешелъ въ г. Наровчатъ Пензенской губ. на должность городового и земскаго врача и здъсь вначалґ зав бдываль женскимъ отдығленіемъ городской и убздной земской больницы (30 кроватей съ гинекологическимъ и родильнымъ отдъ̆леніями). Въ Мартъ 1894 года назначенъ быль старшимъ врачемъ той же больницы (100 кроватей). Вь апрьль' 1895 года перешель на Ю. З. ЗЖ. Д. участковымъ врачемъ, каковымь состоить и понынб.

Кузнеиовг, Николай Федоровичъ, окончиль гимнавію въ Владивостокъ, а университетскій курсъ въ 1894 году въ Кіевъ. Въ настоящее время служитъ вемскимь врачемъ въ Хорольскомъ уб̆здӗ Полтавской губ. въ м. Остапьт.

IIо произведенной баллотировкъ д-ра Дацюовг и Кузнещовг избраны въ дтйствительные члень Общества бильшинствомъ голосовъ.

\section{Предсъдатель Г. Рейнъ.}

Секретарь Г. Писемскій. 